\title{
Influence of integrated soil fertility management in wheat and tef productivity and soil chemical properties in the highland tropical environment
}

\author{
G. Agegnehu ${ }^{1 *}$, C. vanBeek ${ }^{2}$ and M. I. Bird ${ }^{1}$

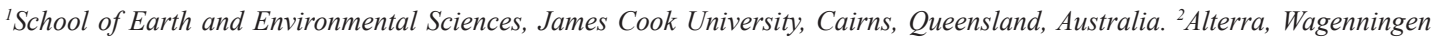 \\ University and Research Centre, the Netherlands. "Corresponding author: getachew.jenberu@my.jcu.edu.au
}

\begin{abstract}
Soil fertility depletion and soil quality decline have been threatening the ecological and economic sustainability of crop production. In order to improve soil fertility and nutrient management approaches, on-farm integrated soil fertility management (ISFM) trials were conducted to evaluate the effects of organic and inorganic fertilizers on wheat (Triticum estivum L.) and tef (Eragrostis tef) yield and soil fertility in the highland Nitisol area of Ethiopia during 2010 and 2011 cropping seasons. The treatments were five selected combinations of $\mathrm{N}$ and $\mathrm{P}$, manure and compost. These included control, farmers' practice (23/10 $\left.\mathrm{kg} \mathrm{NP} \mathrm{ha}^{-1}\right)$, recommended NP rate (60/20 $\left.\mathrm{kg} \mathrm{NP} \mathrm{ha}^{-1}\right)$, $50 \%$ of recommended NP rate $\left(30 / 10 \mathrm{NP} \mathrm{kg} \mathrm{ha} \mathrm{N}^{-1}\right)+50 \%$ manure and compost as inorganic $\mathrm{N}$ equivalence $(3.25$ tons $\mathrm{ha}^{-1}$ ). and $50 \%$ manure $+50 \%$ compost as $\mathrm{N}$ equivalence. Results revealed that yields of wheat and tef, and some soil chemical properties significantly responded to the different soil fertility management treatments. The application of $60 / 20 \mathrm{~kg} \mathrm{NP} \mathrm{ha}^{-1}$ and $30 / 10 \mathrm{~kg} \mathrm{NP} \mathrm{ha}^{-1}$ with $50 \%$ manure and compost as $\mathrm{N}$ equivalence increased mean grain yield of wheat by 151 and $129 \%$ respectively compared to the control, and by 85 and $68 \%$ respectively compared to the farmers' treatment $\left(23 / 10 \mathrm{~kg} \mathrm{NP} \mathrm{ha}^{-1}\right)$. Similarly, the same treatments increased tef grain yield by 141 and $122 \%$ compared to the control, and by 44 and $33 \%$ compared to the farmers' treatment.The application of compost or manure with half the recommended NP fertilizer rate resulted in a comparable yield as that of full NP dose, which could beconsidered as an alternative option for sustainable soil health and crop productivity. In conclusion, the two year result showed that the application of ISFM may optimize yield of wheat and tef as well as improve the fertility status of the soil.
\end{abstract}

Keywords: Compost, integrated soil fertility management, manure, NP fertilizer, Nitisols, tef, wheat

\section{Introduction}

Soil fertility decline is the pressing issue in subSaharan Africa (Sanchez et al. 1997; Bationo et al. 2006; Sangingaand Woomer, 2009; Vanlauwe et al., 2010). Soil degradation is the most serious bio-physical constraint limiting crop productivity in Ethiopia (FAO, 1998; Zeleke et al. 2010). The problem is more serious in the highlands where most of the human and livestock population is found. A recent study has showed that the average annual soil loss from agricultural land is estimated to be 137 tons ha ${ }^{-1}$ per year for the Ethiopian highlands,which is approximately an annual soil depth loss of $10 \mathrm{~mm}$ (Spielman et al., 2009; Zeleke et al., 2010). 
In the highlands, long years of cultivation coupled with deforestation and overgrazing with the intention of expanding farmland to meet the needs of the everincreasing human and livestock population has not only led to severe land degradation and deterioration in the fertility of agricultural soils but also jeopardized the survival of the rural population who depends on agriculture. Studies estimated that cost of land degradation varies between $2-3 \%$ of agricultural GDP (Zeleke et al., 2010). This is mainly due to the complete removal of crop residues from farm lands, low levels of fertilizer application, use of manure and crop residue as a source of fodder and fuel in place of soil fertility maintenance, lack of appropriate soil conservation practices and cropping systems (FAO, 1998; Elias, 2002; Haileselassie et al., 2005; 2006). Thus, the mitigation of soil fertility depletion is currently a pressing issue and major national concern.

Tef (Eragrostis tef) and wheat (Triticum aestivum L.) are mainly cultivated as mono-crops and usually involved in crop rotations (tef-wheat-food legumes). Wheat and tef show an increasing trend in terms of area coverage, which is about 2.56 and 1.42 million ha, respectively (CSA, 2009). However, their corresponding productivity (1.17 and 1.63 tons ha $\left.\mathrm{h}^{-1}\right)$ is very lowdue to poor soil fertility and traditional crop management practices. This is true especially for $\mathrm{N}$ and $\mathrm{P}$ fertilizers because of continuous cropping of cereals and low level of fertilizer application (Yirga et al., 2002; Agegnehu and Bekele, 2005). Moreover, farmers who have the experience and resources to prepare compost often manage to have much less than the amount required.

The most common fertilizers used in Ethiopia are diammonium phosphate (DAP) and urea. Such unbalanced and continuous application of limited fertilizers both in amount and type may aggravate the depletion of other important nutrients such as K, $\mathrm{Mg}, \mathrm{Ca}, \mathrm{S}$ and micro-nutrients not supplied by the chemical fertilizers and may also lead to chemical soil degradation (Dibabe et al., 2007). Chemical fertilizers are also costly for farmers to apply the recommended rates. On the other hand, sole application of organic matter is constrained by access to sufficient organic inputs, low nutrient content, high labor demand for preparation and transporting. For instance, the low $\mathrm{P}$ content of most organic materials indicates the necessity of external sources of $\mathrm{P}$ to sustain crop productivity. Thus, the integration of organic and inorganic sources may improve and sustain crop yields without degrading soil fertility status.

Recent studies have indicated that the interaction effect between combined inputs and practices can provide almost double the crop yield benefits compared to fertilizers applied separately (Agegnehu and Bekele, 2005; Våje, 2007; Dercon and Hill, 2009). For instance, yield gains have been relatively substantial especially for wheat and maize compared to tef when combined with the adoption of optimal farm management practices. In order to improve the resource base 'soil' and crop yield thereby the livelihood of farmers, ISFM project was initiated in 2009. According to Vanlauwe et al. (2010, p. 19), ISFM is a set of soil fertility management practices that necessarily include the use of fertilizer, organic inputs, and improved seed combined with knowledge on how to adapt these practices to local conditions, and aiming to maximize agronomic use efficiency of the applied nutrients and thus crop productivity. It is often believed that ISFM-based crop production systems play important roles in restoring soil fertility and availability of plant nutrients, enhancing crop growth and productivity; they are profitable, socially just, nutrient-dense and resilient (Vanlauwe et al., 2010; Zeleke et al., 2010). Therefore, the objectives of this experiment were to determine the effects of inorganic and organic fertilizers on soil productivity and crop yield, to adapt innovative approaches to develop ISFM technologies that help alleviate crop production related constraints and incorporate into prototype land-use and production systems of small holder farmers. 


\section{Materials and Methods}

\subsection{Experimental set-up and execution}

The effects of ISFM were investigated on the yield of wheat and tef under on-farm condition in 2010 and 2011 cropping seasons. After selecting five farms for each crop, the experiments were undertaken on weathered reddish-brown Nitisol areas of Welmera and Addisalem Districts of West Shewa, central highlands of Ethiopia.

The experiment comprised 5 treatments, viz. (i) control - without fertilizer, (ii) farmers' practice $(23 / 10 \mathrm{~kg} \mathrm{NP}$ $\left.\mathrm{ha}^{-1}\right)$, (iii) recommended NP rate $\left(60 / 20 \mathrm{~kg} \mathrm{NP} \mathrm{ha}^{-1}\right)$, (iv) $50 \%$ of NP recommended rate $\left(30 / 10 \mathrm{NP} \mathrm{kg} \mathrm{ha}^{-1}\right)+$ $50 \%$ manure and compost recommended $\mathrm{N}$ equivalence (3.25 tons ha ${ }^{-1}$ ), and (v) $50 \%$ manure $+50 \%$ compost recommended $\mathrm{N}$ equivalence ( 2 tons manure $\mathrm{ha}^{-1}+$ 4.5 tons compost $\mathrm{ha}^{-1}$ ). The design employed was completely randomized block (RCB), and the farmers who hosted the trials were used as replications, where each plot size was $10 \mathrm{~m}$ by $10 \mathrm{~m}$.

Manure and compost were prepared following the standard procedure for compost preparation (Inckel et al., 2005). Samples were collected from well-decomposed manure and compost before they were applied in the field. Nitrogen and P were analyzed at the soil and plant analysis laboratory of Holetta Agricultural Research Center before the onset of the trial to calculate the mineral fertilizer equivalence using the same analytical procedures that were used for soil. Manure and compost were applied 21 days before sowing and thoroughly mixed in the upper 15-20 cm soil depth. Nitrogen and $P$ fertilizers were applied in the form of urea and DAP respectively. To minimize loss and increase efficiency, $\mathrm{N}$ was applied as a split at planting and during the maximum growth period of the crops (tillering stage). Phosphorus was applied at planting. Wheat (var. HAR604) and Tef (var. Kuncho, DZ-Cross 387) were planted at the recommended seed rates and sowing dates. Wheat was sown at the rate of $175 \mathrm{~kg} \mathrm{ha}^{-1}$ in the fourth week of June, and tef at the rate of $25 \mathrm{~kg} \mathrm{ha}^{-1}$ in mid-July. Other recommended agronomic practices were applied during the crop growth period according to common practices.

\subsection{Data collection and analysis}

Composite soil samples were collected from each site at 0-30 cm soil depth before treatment application (Table 1) and immediately after harvesting for the analyses of soil $\mathrm{pH}$, total organic carbon (OC), total $\mathrm{N}$, available $\mathrm{P}$, exchangeable $\mathrm{K}, \mathrm{Na}$ and cation exchange capacity (CEC). Soil reactions $(\mathrm{pH})$ were measured in $\mathrm{H}_{2} \mathrm{O}$ with a liquid to solid ratio of 2.5:1. Organic carbon was determined according to Walkley and Black method and total nitrogen using Kjeldahl method. Available phosphorus was determined using the Bray-II method. Exchangeable cations and cation exchange capacity were also analyzed using ammonium acetate method.

Data on grain yield, total biomass, thousand grain weight, harvest index and straw yields of wheat and tef as appropriate were collected. To estimate grain yield and total biomass an area of $6 \mathrm{~m}$ by $6 \mathrm{~m}$ (36 $\mathrm{m}^{2}$ ) was harvested from each plot. Total biomass and grain yields recorded on oven-dry-weight basis were converted to $\mathrm{kg} / \mathrm{ha}$ for statistical analysis. The SAS statistical computer package (SAS, 2002) was used to test for presence of outliers and normality of residuals. The total variability for each trait was quantified using separate and pooled analysis of variance over years using the following model (Gomez and Gomez, 1984).

$$
P_{i j k=} \mu+Y_{i}+R_{j(\mathrm{i})}+T_{k}+T Y_{(i \mathrm{k})}+e_{i j k}
$$

Where $P_{i j k}$ is total observation, $\mu=$ grand mean, $Y_{i}=$ effect of the $i^{\text {th }}$ year, $R_{j(i)}$ is effect of the $j^{\text {th }}$ replication (within the $i^{\text {th }}$ year), $T_{k}$ is effect of the $\mathrm{k}^{\text {th }}$ treatment, $\mathrm{TY}_{\text {(ik) }}$ is the interaction of $\mathrm{k}^{\text {th }}$ treatment with $\mathrm{i}^{\text {th }}$ year and $\mathrm{e}_{\mathrm{ijk}}$ is the random error. Results were presented as means and least significance difference (LSD) at $5 \%$ probability level was used to establish differences among means, and linear regression was performed between grain yield and some relevant yield component parameters for both crops. 
Table 1. Soil chemical characteristics of the trial sites before application of treatments

\begin{tabular}{llllllll}
\hline Trial fields & $\begin{array}{l}\mathrm{pH} \\
\left(\mathrm{H}_{2} \mathrm{O}\right)\end{array}$ & $\begin{array}{l}\text { Nitrogen } \\
(\%)\end{array}$ & $\begin{array}{l}\text { Phosphorus } \\
(\mathrm{ppm})\end{array}$ & $\begin{array}{l}\mathrm{OC} \\
(\%)\end{array}$ & \multicolumn{3}{c}{ Exchangeable cationsmeq/100g } \\
\cline { 6 - 7 } Wheat & & & & & $\mathrm{Na}$ & $\mathrm{K}$ & $\mathrm{CEC}$ \\
\hline 1 & 5.95 & 0.14 & 7.00 & 1.56 & 0.11 & 1.97 & 16.38 \\
2 & 5.08 & 0.15 & 5.80 & 1.52 & 0.13 & 2.25 & 14.96 \\
3 & 5.32 & 0.16 & 6.20 & 1.68 & 0.17 & 1.55 & 24.68 \\
4 & 5.28 & 0.16 & 6.40 & 1.71 & 0.15 & 2.11 & 22.94 \\
Mean & 5.41 & 0.15 & 6.35 & 1.61 & 0.14 & 1.97 & 19.74 \\
\hline Tef & & & & & & & 1.69 \\
\hline 1 & 4.69 & 0.14 & 6.00 & 1.48 & 0.11 & 1.69 & 17.16 \\
2 & 4.77 & 0.16 & 5.60 & 1.56 & 0.11 & 1.69 & 15.64 \\
3 & 5.09 & 0.15 & 5.20 & 1.79 & 0.11 & 2.25 & 14.82 \\
4 & 5.25 & 0.18 & 5.60 & 1.75 & 0.19 & 0.83 & 22.80 \\
5 & 5.35 & 0.18 & 6.30 & 1.87 & 0.17 & 2.39 & 27.28 \\
\hline Mean & 5.03 & 0.16 & 5.74 & 1.69 & 0.14 & 1.77 & 19.54 \\
\hline
\end{tabular}

\section{Results and Discussion}

\subsection{Effects of organic and inorganic fertilizers on soil chemical properties}

Major causes of nutrient depletion in the study area are farming without replenishing nutrients over time, and/or chemical imbalance issues such as soil acidity leading to fixation often driven by continuous cropping of cereals, removal of crop residues, leaching, low levels of fertilizer usage and unbalanced application of nutrients. The contents of $\mathrm{N}$ and $\mathrm{P}$ in the analyzed manure before application were $1.54 \%$ and $0.41 \%$ respectively on $50 \%$ dry-weight basis, and $0.72 \% \mathrm{~N}$ and $0.23 \% \mathrm{P}$ in compost on $55 \%$ dry weight basis. Soil analytical data is important to identify the level of nutrients in the soil and to determine suitable rates and types of fertilizers for recommendation. Soil analysis results for samples taken before the applications of treatments were found to be sub-optimal for crop production. The nutrient contents of the soil type used in this study were correspondingly in agreement with the characteristics of the soil identified by farmers as low fertility. As presented in Table 1, the soil $\mathrm{pH}$, total $\mathrm{N}, \mathrm{OC}$, available $\mathrm{P}$ and the $\mathrm{CEC}$ were found to be below the optimum requirement for wheat and tef production. In most cases soils whose $\mathrm{pH}$ is less than 5.5 are deficient in Ca, Mg and P (Marschner, 1995; Agegnehu and Sommer, 2000).

Results of soil analysis after harvesting wheat and tef revealed that the application of different soil fertility management treatments significantly $(p<0.05$ and $p$ $<0.01$ ) affected organic carbon, total $\mathrm{N}$, available $\mathrm{P}$, nitrate $\mathrm{N}\left(\mathrm{NO}_{3}-\mathrm{N}\right)$ and ammonium $\mathrm{N}\left(\mathrm{NH}_{4}-\mathrm{N}\right)$ analyzed for samples taken after harvesting from trial fields of both crops. Soil $\mathrm{pH}$ of wheat fields was significantly ( $p$ $<0.05$ ) affected by different soil fertility management treatments, but not soil $\mathrm{pH}$ of tef trial sites (Tables 2 and 3). Different soil fertility management treatments had significant effects on post-harvest soil organic carbon content. A significant improvement was observed in organic carbon content compared to the contents of the soil before treatment application.

Relatively higher soil organic carbon was recorded on experimental plots, which received either organic or inorganic and organic nutrient sources (Tables 2 and 3 ) than plots received only inorganic fertilizers. 
Table 2. Effect of different soil fertility management treatments on soil chemical properties after harvesting wheat in the central highlands of Ethiopia

\begin{tabular}{|c|c|c|c|c|c|c|}
\hline $\begin{array}{l}\text { Treatments } \\
\left(\mathrm{kg} \mathrm{ha}^{-1}\right)\end{array}$ & $\begin{array}{c}\mathrm{pH} \\
\left(\mathrm{H}_{2} \mathrm{O}\right)\end{array}$ & $\begin{array}{l}\mathrm{OC} \\
(\%)\end{array}$ & $\begin{array}{c}\mathrm{N} \\
(\%)\end{array}$ & $\begin{array}{c}\mathrm{P} \\
(\mathrm{ppm})\end{array}$ & $\begin{array}{c}\mathrm{NO}_{3^{-}} \\
\mathrm{N} \\
(\mathrm{ppm})\end{array}$ & $\begin{array}{c}\mathrm{NH}_{4-} \\
\mathrm{N} \\
(\mathrm{ppm})\end{array}$ \\
\hline Control & 5.57 & 1.36 & 0.14 & 9.40 & 6.00 & $8.55 \mathrm{~b}$ \\
\hline Farmers NP rate $(23 / 10 / 0)$ & 5.36 & 1.61 & 0.16 & 11.00 & $6.33 b$ & 9.25 \\
\hline Recommended NP $(60 / 20 / 0)$ & 5.26 & 1.83 & 0.17 & 15.55 & 7.20 & 9.78 \\
\hline $\begin{array}{l}50 \% \text { of recommended } \mathrm{NP}+50 \% \text { manure }+ \\
50 \% \text { compost as } \mathrm{N} \text { equivalence }\end{array}$ & 5.76 & 2.06 & 0.18 & 15.57 & 10.60 & 13.60 \\
\hline $\begin{array}{l}50 \% \text { Manure }+50 \% \text { compost as } \mathrm{N} \\
\text { equivalence }\end{array}$ & 6.15 & 1.98 & 0.17 & 15.52 & 9.78 & 10.70 \\
\hline F-probability (treatment) & $*$ & $* *$ & $*$ & $* *$ & $* *$ & $*$ \\
\hline $\mathrm{LSD}_{0.05}$ & 0.39 & 0.21 & 0.02 & 3.40 & 1.82 & 2.97 \\
\hline CV (\%) & 4.55 & 13.20 & 2.69 & 16.40 & 14.81 & 18.61 \\
\hline
\end{tabular}

$*, * *=$ significant at $p<0.05$ and $p<0.01$, respectively; $\mathrm{NS}=$ Not significant

Table 3. Effect of different soil fertility management treatments on soil chemical properties after harvesting tef in central Ethiopian highlands

\begin{tabular}{lcccccc}
\hline $\begin{array}{l}\text { Treatments-N/PK/organic } \\
\left(\mathrm{kg} \mathrm{ha}^{-1}\right)\end{array}$ & $\begin{array}{c}\mathrm{pH} \\
\left(\mathrm{H}_{2} \mathrm{O}\right)\end{array}$ & $\begin{array}{c}\mathrm{OC} \\
(\%)\end{array}$ & $\begin{array}{c}\mathrm{N} \\
(\%\end{array}$ & $\begin{array}{c}\mathrm{P} \\
(\mathrm{ppm})\end{array}$ & $\begin{array}{c}\mathrm{NO}_{3^{-}} \\
\mathrm{N}\end{array}$ & $\begin{array}{c}\mathrm{NH}_{4^{-}} \\
\mathrm{N}\end{array}$ \\
\hline Control & & & & & $(\mathrm{ppm})$ & $(\mathrm{ppm})$ \\
Farmers NPK rate $(23 / 10 / 0)$ & 5.19 & 1.29 & 0.17 & 7.75 & 6.23 & 5.93 \\
Recommended NPK $(60 / 20 / 0)$ & 5.05 & 1.56 & 0.17 & 8.40 & 6.98 & 7.00 \\
$50 \%$ of recommended NPK (30/10/0)+ & 5.33 & 1.79 & 0.18 & 11.85 & 9.43 & 8.38 \\
$50 \%$ manure + 50\% compost N & 5.55 & 2.30 & 0.19 & 11.20 & 10.70 & 12.90 \\
equivalence & & & & & & \\
$50 \%$ Manure +50\% compost as N & & & & & & \\
equivalence & 5.48 & 2.22 & 0.18 & 10.25 & 10.13 & 8.40 \\
\hline F-probability & & & & & & \\
LSD $_{0.05}$ & $\mathrm{NS}$ & $* *$ & $*$ & $*$ & $*$ & $* *$ \\
CV $(\%)$ & 0.31 & 0.27 & 0.01 & 2.73 & 3.53 & 3.03 \\
\hline
\end{tabular}

$*, * *=$ significant at $p<0.05$ and $p<0.01$, respectively; $\mathrm{NS}=$ Not significant 
The mean soil $\mathrm{pH}$ of wheat trial sites ranges between 5.26 and 6.15 , and 5.05 and 5.55 for tef trial sites, which is moderately acidic and in most cases sub-optimal for the production of most field crops. The mean total $\mathrm{N}$ and available $\mathrm{P}$ were found to be above the critical levels. These values for wheat fields were in ranges of 0.16 $0.18 \%$ for $\mathrm{N}$ and $9.40-15.57 \mathrm{ppm}$ for $\mathrm{P}, 0.17-0.19 \%$ for $\mathrm{N}$ and $7.75-11.85 \mathrm{ppm}$ for $\mathrm{P}$ for tef fields. Both $\mathrm{N}$ and $\mathrm{P}$ values were relatively higher for wheat fields than tef trial fields. Nonetheless, based on the categories of soil characteristics, both nutrient values fall in the medium ranges (Jones, 2003). Relatively higher total N, $\mathrm{NO}_{3}-\mathrm{N}$ and $\mathrm{NH}_{4}-\mathrm{N}$ values were obtained from the plots treated with $50 \%$ recommended NP and $50 \%$ organic fertilizer as inorganic $\mathrm{N}$ equivalence followed by plots treated by $100 \%$ manure and compost as recommended inorganic $\mathrm{N}$ equivalence (Tables 2 and 3). Significant differences in $\mathrm{P}$ values were not observed among inorganic and organic fertilizer treated plots of both wheat and tef fields (Tables 2 and 3). In general, the soil analysis results for samples taken after harvesting revealed that integrated use of organic and inorganic nutrient sources could result in significant improvement in the overall condition of the soil as well as agricultural productivity if the best alternative option is adopted by producers in the area. Kang et al. (2005) reported that the long-term application of organic manures in rice/corn-wheat cropping system increased the index value as it increased the nutrient index, microbial index and crop index of soils. Similar research findings also indicated that soils fertilized with manure had higher contents of organic matter (Edmeades, 2003; Srivastava et al., 2012) and numbers of micro-fauna than fertilized soils, and were more enriched in $\mathrm{P}, \mathrm{K}, \mathrm{Ca}$ and $\mathrm{Mg}$ in topsoils and nitrate $\mathrm{N}, \mathrm{Ca}$ and $\mathrm{Mg}$ in sub-soils (Edmeades, 2003). Agegnehu and Bekele (2005) also reported that the soil $\mathrm{pH}$, total $\mathrm{N}$ and organic matter content, $\mathrm{CEC}$ and exchangeable cations were significantly improved due to the application of farmyard manure. Haileselassie et al. (2006) indicated that N, P and K balances in the wheat based cropping system of central highlands of Ethiopia were $-62,-5$ and $-47 \mathrm{~kg} \mathrm{ha}^{-1}$ respectively, in which based on altitudinal classification the highest nutrient depletion was recorded at foot slopes in Dega, and at the mid-slopes in Woina Dega.

\subsection{Productivity of wheat}

The combined analysis of variance over two years revealed that the effect of cropping season was highly significant $(p<0.001)$ on total biomass, straw yield and harvest index of wheat and significant $(p<0.05)$ on grain yield. The highest mean grain yield and harvest index of wheat were recorded in 2011 cropping season, implying that the adverse effect of yellow rust disease on wheat in 2010 resulted in a remarkable reduction in grain yield (Table 4). Hence, though grain yield increment trend was observed due to the applications of inorganic and organic nutrient sources the actual yield achieved did not reflect the well growth of wheat in 2010 cropping season due to the incidence of yellow rust disease.

Results indicated that productivity of wheat was significantly affected by different soil fertility treatment levels. Applications of inorganic and organic nutrient sources either alone or in combination had a significant $(p$ $<0.001$ and $p<0.01$ ) effect on grain yield, total biomass and harvest index of wheat, but not on its thousand grain weight. Analysis of variance over two years indicated that the year by soil fertility treatment level interaction (YxT) effect was significant $(p<0.05$ and $p<0.001)$ for wheat grain yield, total biomass and harvest index; but not for thousand grain weight (Table 4).

Higher wheat grain yield, total biomass and straw yield were obtained from the application of organic and inorganic plant nutrient sources. Yield increases were over $100 \%$, owing to soil fertility status improvement (Table 3). The application of recommended NP at the rate of $60 / 20 \mathrm{~kg} \mathrm{NP} \mathrm{ha}^{-1}$ increased wheat grain yield by about $151 \%$ and $85 \%$ compared to the control and the lowest farmers' NP rate respectively. Similarly, application of half the recommended $\mathrm{N}$ and $\mathrm{P}$ rate and half the recommended rate of manure and compost as inorganic $\mathrm{N}$ equivalence resulted in yield advantages of about $129 \%$ and $68 \%$ compared to the control and the lowest farmers' rate respectively. 
Table 4. Response of wheat grain yield (GY), total biomass (TB), straw yield (SY), harvest index (HI) and thousand grain weight (TGW) to ISFM treatments on Nitisols of central Ethiopian highlands

\begin{tabular}{|c|c|c|c|c|c|}
\hline $\begin{array}{l}\text { Treatments-N/PK/organic } \\
\left(\mathrm{kg} \mathrm{ha}^{-1}\right)\end{array}$ & $\begin{array}{c}\text { GY } \\
\left(\mathrm{kg} \mathrm{ha}^{-1}\right)\end{array}$ & $\begin{array}{c}\text { TB } \\
\left(\mathrm{kg} \mathrm{ha}^{-1}\right)\end{array}$ & $\begin{array}{l}\text { Straw yield } \\
\left(\mathrm{kg} \mathrm{ha}^{-1}\right)\end{array}$ & $\begin{array}{l}\mathrm{HI} \\
(\%)\end{array}$ & $\begin{array}{c}\text { TGW } \\
(\mathrm{g})\end{array}$ \\
\hline \multicolumn{6}{|l|}{ Year } \\
\hline 2010 & $2286 b$ & $6283 a$ & $3997 a$ & $36.4 \mathrm{~b}$ & 33.9 \\
\hline 2011 & $2466 a$ & $5618 b$ & $3152 b$ & $43.8 \mathrm{a}$ & 34.7 \\
\hline F-probability & $*$ & $* * *$ & $* * *$ & $* * *$ & NS \\
\hline $\mathrm{LSD}_{0.05}$ & 144.1 & 456.8 & 352.0 & 2.12 & 1.60 \\
\hline \multicolumn{6}{|l|}{ ISFM-treatments (T) } \\
\hline Control & $1258 \mathrm{e}$ & $3644 d$ & $2387 d$ & $34.5 \mathrm{bc}$ & 35.2 \\
\hline Farmers NPK rate $(23 / 10 / 0)$ & $1713 d$ & $4864 c$ & $2932 c$ & $35.2 b$ & 34.0 \\
\hline Recommended NPK $(60 / 20 / 0)$ & $3164 a$ & $7678 \mathrm{a}$ & $4514 a$ & $41.2 \mathrm{ab}$ & 33.2 \\
\hline $\begin{array}{l}50 \% \text { of recommended NPK }(30 / 10 / 0)+50 \% \\
\text { manure and compost as N equivalence }(3.25 \mathrm{t} / \mathrm{ha})\end{array}$ & $2882 b$ & $7073 b$ & $4192 a$ & $40.8 \mathrm{ab}$ & 32.9 \\
\hline $\begin{array}{l}50 \% \text { Manure }+50 \% \text { compost }(6.5 \mathrm{t} / \mathrm{ha}) \text { as } \mathrm{N} \\
\text { equivalence }\end{array}$ & $2646 c$ & $6219 c$ & $3574 b$ & $42.5 \mathrm{a}$ & 34.9 \\
\hline $\mathrm{LSD}_{0.05}$ & 228.58 & 679.14 & 556.6 & 2.97 & 2.50 \\
\hline \multicolumn{6}{|l|}{ F-probability } \\
\hline Treatment $(\mathrm{T})$ & 0.0001 & 0.0001 & 0.0001 & 0.0001 & 0.2749 \\
\hline $\mathrm{Y} \times \mathrm{T}$ & $*$ & $* * *$ & $* * *$ & $* * *$ & NS \\
\hline CV (\%) & 9.35 & 11.94 & 15.41 & 7.18 & 7.22 \\
\hline
\end{tabular}

$*, * * *=$ significant at $p<0.05$ and $p<0.001$, respectively; NS $=$ Not significant. Means in a column with the same letter are not significantly different $(p<0.05)$.

Application of $100 \%$ recommended manure and compost as inorganic $\mathrm{N}$ equivalence also increased wheat grain yield by $110 \%$ and $55 \%$ compared to the control that is non-treated plot and farmers' rate of $32 / 10$ $\mathrm{kg} \mathrm{NP} \mathrm{ha-1}$ respectively (Table 4). The results of this study has clearly elucidated that if the application rate of fertilizers either as inorganic, organic or the combination of both is at least doubled under farmers' field condition the yield gain will be more than double compared to the control plot and more than $50 \%$ compared to the farmers' applied rate. Furthermore, the study proved the significance of the ISFM treatments containing both organic and inorganic forms under farmers' field condition that they could be considered as alternative options for sustainable soil and crop productivity in the degraded highlands of Ethiopia.

The works of different researchers showed that the integrated application of NP fertilizer with manure resulted in a significant increase in nutrient concentration and uptake, grain and straw yields of wheat (Agegnehu and Bekele, 2005; Matsi et al., 2003; Sharma et al., 1990). The application of manure influences directly the availability of native or applied phosphorus (Sharma 
et al., 1990). It was also found that the application of manure made the soil more porous and pulverised which allows better root growth and development and significantly increased the root CEC at each stage of growth, indicating that its application may prove beneficial for crop nutrition and yield (Sharma et al., 1990). Gruhn et al. (2000) reported that continuously cropped wheat, without the benefit of organic and inorganic fertilizers, typically has low yields (1.2 tons $\left.\mathrm{ha}^{-1}\right)$. The application of organic and inorganic fertilizers can increase average wheat yields to 6-7 tons $\mathrm{ha}^{-1}$. Wheat yields are highest $\left(9.4\right.$ tons ha $\left.{ }^{-1}\right)$ when farmyard manure is applied, wheat is grown in rotation and inorganic fertilizers are used to top-up $\mathrm{N}$ availability (Gruhn et al., 2000).

Due to the widespread occurrence of yellow rust disease in 2010 , the highest wheat harvest index (43.8\%) was recorded in 2011, indicating that better grain yield was also obtained in this season. On the other hand, significantly higher harvest indexes were recorded from the organic and inorganic fertilizer and inorganic fertilizer treatments compared to farmers' practice and control treatments (Table 4). Likewise, despite nonsignificant differences, the highest thousand grain weight was recorded in 2011. The linear regression analysis revealed that wheat grain yield was significantly positively correlated with total biomass $\left(\mathrm{R}^{2}=0.80\right)$, but weakly correlated with harvest index $\left(\mathrm{R}^{2}=0.18\right)$. Grain yield was most strongly correlated with total biomass (Figure 1). From this result, it can be concluded that high total biomass is the trait associated with good performance of wheat. Similar research findings have also indicated that grain yield is correlated positively with total biomass and straw yield, spike length and number of productive tillers of barley and wheat (Sinebo, 2002; Agegnehu and Bekele, 2005).

\subsection{Productivity of tef}

Although some of the major limitations of tef production are moisture stress and nutrient deficiencies, mainly of $\mathrm{N}$ and $\mathrm{P}$, it performs well on various soil types and diverse agro-ecological zones of the country. The combined analysis of variance over two years revealed that tef positively responded to different soil fertility management treatments. Cropping season had significant effect on straw yield and harvest index of tef, but not on tef grain yield and total biomass indicating that harvest index of tef is sensitive to cropping season. The application of organic and inorganic fertilizers had a highly significant $(p<$ 0.001) effect on the total biomass, grain and straw yields of tef. The interaction of cropping season and different soil fertility treatments was not significant (Table 5).

The crop responds well to fertilizer and crop management practices, where the highest tef grain yield was obtained with application of about $60 / 20 \mathrm{~kg}$ $\mathrm{NP} \mathrm{ha}{ }^{-1}$ on Nitisols of the central Ethiopian highlands. The application of the recommended inorganic NP fertilizer at the rate of $60 / 20 \mathrm{~kg} \mathrm{NP} \mathrm{ha}^{-1}$ increased tef grain yield and total biomass by about $141 \%$ and $149 \%$ compared to the control, and $44 \%$ and $53 \%$ compared to the farmers' NP rate respectively. Application of $50 \%$ recommended NP rate and 50\% manure and compost as inorganic $\mathrm{N}$ equivalence resulted in grain yield and total biomass increments of $122 \%$ and $113 \%$ compared to the control, and $33 \%$ and $31 \%$ compared to the farmers' treatment (23/10 kg NP ha-1) (Table 5). A similar trend was observed in the tef grain yield and total biomass due to the application of full dose of manure and compost as inorganic $\mathrm{N}$ equivalence. Research findings indicate that growth and yields of tef have responded differently to application of $\mathrm{N}$ and P on different soil types (Mamo et al., 2001; Ayalew, 2011). For instance, tef has shown a highly significant response to $\mathrm{N}$ fertilizer both on Vertisols and Nitisols, but applying $\mathrm{N}$ fertilizer beyond the recommended rate may aggravate lodging. In contrast, the response of tef to $\mathrm{P}$ has been more important on highly weathered red soils (Nitisols) which fix considerable quantity of applied P than on Vertisols (Mamo et al., 2001), which is in agreement with the results of this study. According to these authors a maintenance level of about $10 \mathrm{~kg} \mathrm{P}$ $\mathrm{ha}^{-1}$ could be adequate for tef on Vertisols, which may reach up to $30 \mathrm{~kg} \mathrm{P} \mathrm{ha}^{-1}$ on Nitisols. 


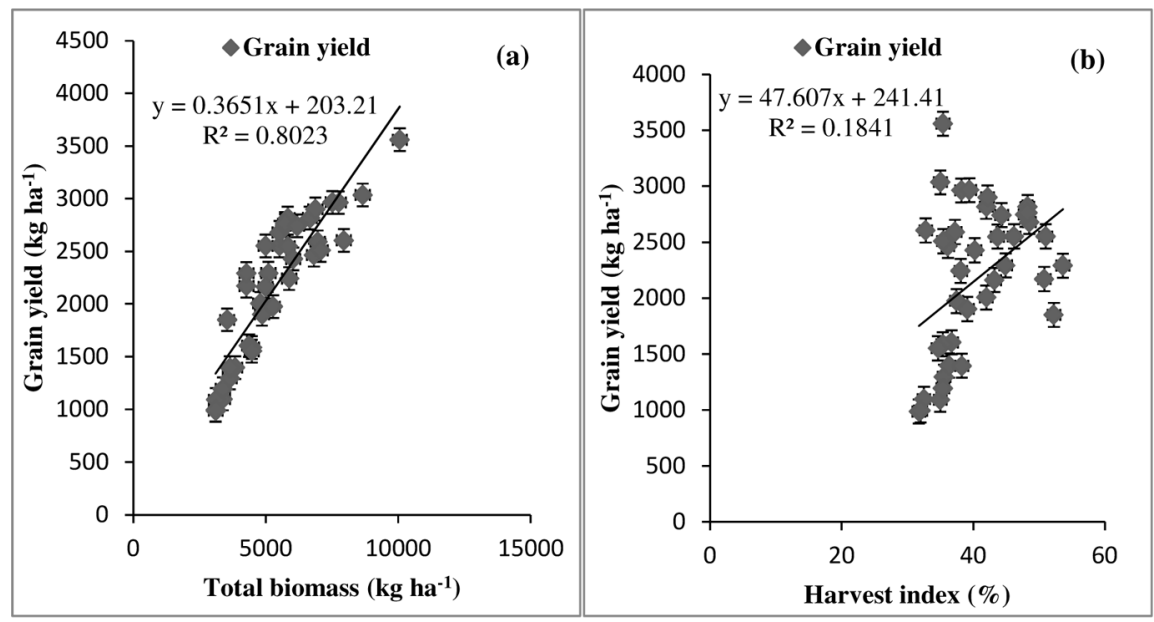

Figure 1. Correlation of wheat grain yield with total biomass (a) and harvest index (b) with standard error bars

The results of this study indicate that there is a potential to increase tef yield through improved soil fertility and crop management practices. This means that the fertility status of soils in the highlands of the country needs to be greatly improved so as to achieve the required output. On station and on-farm research findings indicate that up to 2.5 tons ha $^{-1}$ of tef yield can be obtained under adequate fertilization and improved agronomic practices (Mamo et al., 2001), while national average yield is yet about 1.17 tons ha ${ }^{-1}$ (CSA, 2009). Similar results of agronomic trials showed that tef yield can be doubled by the combined use of high yielding varieties and applying both macro-and micro-nutrients such as zinc and copper (Berhe, 2010).

Significantly higher harvest index of tef was recorded in 2010 (Table 5). The harvest index of tef is very low compared to other cereal crops, implying that the total biomass or straw yield of tef is very high compared to its grain yield. In most cases, when the crop performance in terms of growth is high, lodging occurs which could tremendously decrease grain yield of tef. This is also manifested when high $\mathrm{N}$ fertilizer is applied and where the soil fertility status is high. The highest harvest index in 2010 is an indication for the clear association between grain yield and total biomass. For instance, the lowest total biomass with the corresponding high grain yield and harvest index was obtained in 2010 compared to high total biomass, but relatively low grain yield and harvest index in 2011 (Table 5). On the other hand, despite numerical differences, there was no statistically significant difference among different soil fertility treatments for harvest index. The highest harvest index was recorded on plots treated with half the recommended inorganic and half with organic fertilizer as inorganic $\mathrm{N}$ equivalence. The linear regression analysis showed that tef grain yield was significantly positively correlated with total biomass $\left(\mathrm{R}^{2}=0.84\right)$, but its correlation with tef harvest index was very weak $\left(\mathrm{R}^{2}=0.002\right)$ (Figure 2). From this result, it can be inferred that high total biomass is the trait associated with good performance of tef, but under optimal growth condition and in the absence of lodging that could significantly lower tef grain yield. 
Table 5. Response of tef grain yield (GY), total biomass (TB), straw yield (SY) and harvest index (HI) to ISFM treatments on Nitisols of central Ethiopian highlands

\begin{tabular}{|c|c|c|c|c|}
\hline $\begin{array}{l}\text { Treatments-N/PK/organic } \\
\left(\mathrm{kg} \mathrm{ha}^{-1}\right)\end{array}$ & $\begin{array}{c}\text { GY } \\
\left(\mathrm{kg} \mathrm{ha}^{-1}\right)\end{array}$ & $\begin{array}{c}\text { TBY } \\
\left(\mathrm{kg} \mathrm{ha}^{-1}\right)\end{array}$ & $\begin{array}{c}\text { SY } \\
\left.\left(\mathrm{kg} \mathrm{ha}^{-1}\right)\right)\end{array}$ & $\begin{array}{l}\mathrm{HI} \\
(\%)\end{array}$ \\
\hline \multicolumn{5}{|l|}{ Year } \\
\hline 2010 & 1628 & 5684 & $4101 b$ & $28.6 \mathrm{a}$ \\
\hline 2011 & 1583 & 6314 & $4686 a$ & $25.8 \mathrm{~b}$ \\
\hline F-probability & NS & NS & $*$ & * \\
\hline $\mathrm{LSD}_{0.05}$ & 134 & 619 & 517 & 2.1 \\
\hline \multicolumn{5}{|l|}{ ISFM-treatments (T) } \\
\hline Control & $853 \mathrm{~d}$ & $3232 d$ & $2379 d$ & 26.4 \\
\hline Farmers NPK rate $(23 / 10 / 0)$ & $1427 \mathrm{c}$ & $5250 \mathrm{c}$ & $3824 \mathrm{c}$ & 27.2 \\
\hline Recommended NPK (60/20/0) & $2057 \mathrm{a}$ & $8050 \mathrm{a}$ & $5993 a$ & 25.6 \\
\hline $50 \%$ of recommended NPK $(30 / 10 / 0)+50 \%$ & $1896 \mathrm{ab}$ & $6895 b$ & $4998 b$ & 27.5 \\
\hline \multicolumn{5}{|l|}{ Manure $+50 \%$ compost as $\mathrm{N}$ equivalence } \\
\hline \multicolumn{4}{|l|}{ equivalence } & 27.3 \\
\hline $\mathrm{LSD}_{0.05}$ & 233 & 1077 & 900 & 3.4 \\
\hline \multicolumn{5}{|l|}{ F-probability } \\
\hline Treatment (T) & $* * *$ & $* * *$ & $* * *$ & NS \\
\hline $\mathrm{Y} \times \mathrm{T}$ & 0.1364 & 0.7441 & 0.8122 & 0.1959 \\
\hline $\mathrm{CV}$ & 14.2 & 17.5 & 19.9 & 12.0 \\
\hline
\end{tabular}

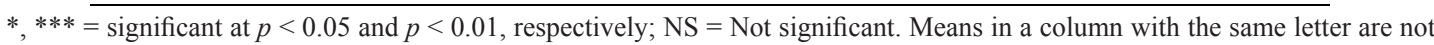
significantly different $(p \leq 0.05)$. 


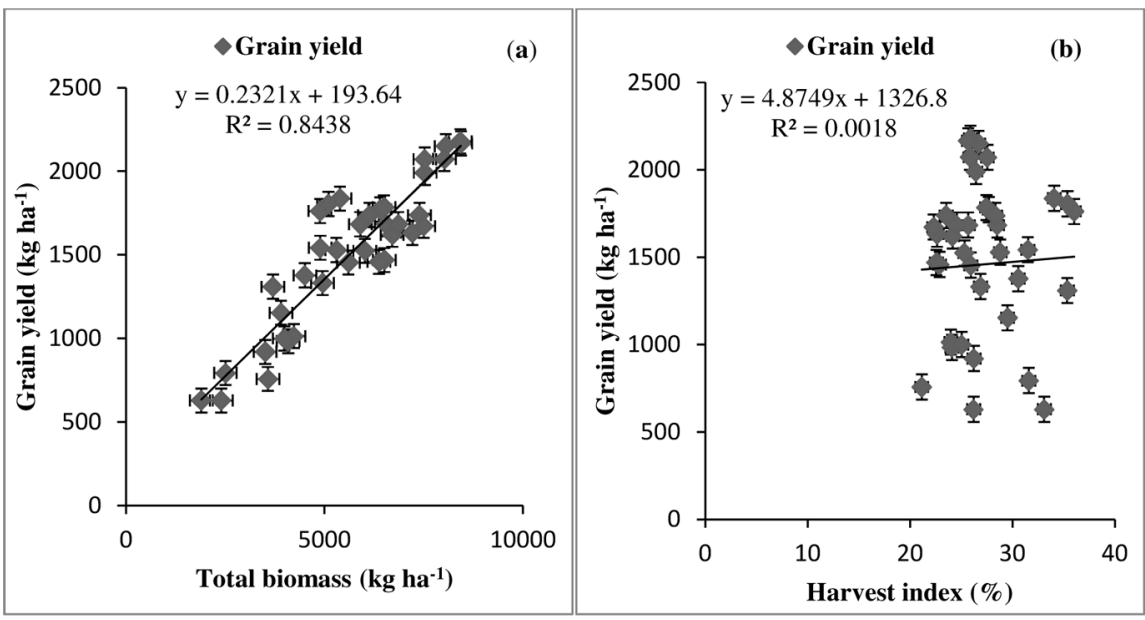

Figure 2. Correlation of tef grain yield with total biomass (a) and harvest index (b) with standard error bars

\section{Conclusion}

Integrated soil fertility management plays a critical role in both short-term nutrient availability and longer-term maintenance of soil organic matter and sustainability of crop productivity in most smallholder farming systems in the tropics. The two year result showed that the integrated application of organic and inorganic fertilizers improved productivity of wheat and tef as well as the fertility status of the soil. Nevertheless, though ISFM is the notably preferred option in replenishing soil fertility and enhancing productivity, it is not yet widely taken up by farmers. The reasons for this are many, which include access or availability of inputs, use of organic resources for other purposes in place of soil fertility, nutrient balancing, collecting, transporting and management of organic inputs and economic returns of investments. These are the key challenges of adoption in the scaling up of such alternative soil fertility management practices to millions of small-scale farmers in the highlands of the country. There is a need, therefore, for research and extension to sort out issues of adoption and scaling up of the available options. In order to address soil fertility problems, potential synergies can be gained by combining technical options with farmers' knowledge as well as training of farmers and development agent on new soil fertility management approaches.

\section{Acknowledgements}

The Ministry of Economic Affairs, Agriculture and Innovations of the Netherlands Government and the Ethiopian Institute of Agricultural Research (EIAR) are highly acknowledged for funding this project. The authors are very grateful to Mr. Chanyalew Mandefro, Mr. Beyene Ofa and Miss Asnakech Dubale for their technical assistance during the execution of the experiments under field condition. The authors would like to thank Mr. Ian Baker for his meticulous language edition of the manuscript. Appreciation is also due for the services of the analytical soil laboratory of Holetta Agricultural Research Center of EIAR. 


\section{References}

Agegnehu, G., Sommer, K. 2000. Optimization of the efficiency of phosphate fertilizers in acidicferralitic soils of the humid tropics. Ethiopian Journal of Natural Resources. 2, 63-77.

Agegnehu, G., Bekele, T. 2005. On-farm integrated soil fertility management in wheat on Nitisols of central Ethiopian highlands. Ethiopian Journal of Natural Resources. 7, 141-155.

Ayalew, A. 2011. Application of NP fertilizers for better production of teff (Eragrostistef (zucc.) trotter) on different types of soils in southern Ethiopia. Journal of Natural Sciences Research. 1(1), 1-11.

Bationo, A., Hartemink, A., Lumgu, O., Naimi, M., Okoth, P., Smaling, E., Thaiombiano, L. 2006. African Soils: Their productivity and profitability of fertilizer use. Africa Fertilizer Summit, Abuja, Nigeria.

Berhe, T. 2010. Increasing productivity of tef: New approaches with dramatic results. Crops productivity, Sasakawa Africa Association, Regional Office, Addis Ababa, Ethiopia.

CSA (Central Statistics Authority). 2008. Statistical bulletin for crop production forecast sample survey.CSA, Addis Ababa, Ethiopia.

Dercon, S., Hill, R.V. 2009. Growth from agriculture in Ethiopia. Identifying key constraints: Paper prepared as part of a study on agriculture and growth in Ethiopia. DFID, UK.

Dibabe, A., Bekele, T., Ahmed, R.V. 2007. The status of micronutrients in Nitisols, Vertisols, Cambisols and Fluvisols in major Maize, wheat, tef and citrus growing areas of Ethiopia. Ethiopian Institute of Agricultural Research, Addis Ababa, Ethiopia, pp: 77-96.
Edmeades, D.C. 2003. The long-term effects of manures and fertilisers on soil productivity and quality: a review. Nutrient Cycling in Agroecosystems. 66, 165-180.

Eghball, B., Power, F. 1999. Composted and noncomposted manure application to conventional and no-tillage systems: corn yield and nitrogen uptake. Agronomy Journal. 91, 819-825.

Elias, E. 2002. Farmers perceptions of change and management of soil fertility. SOS-Sahel and Institute of Development studies. Addis Ababa Ethiopia. 252p.

FAO. 1998. Ethiopia: Soil fertility initiative. Concept paper, report no. 98/028 CP-ETH, FAO/World Bank cooperative program. FAO, Rome.

Gomez, K.A., Gomez, A.A. 1984. Statistical procedures for agricultural research (2nd ed.). New Delhi, India: International Rice Research Institute, 680p.

Gruhn, P., Goletti, F., Yudelman, M. 2000. Integrated nutrient management, soil fertility and sustainable agriculture: current issues and future challenges. Food, Agriculture and the Environment Discussion Paper 32. International Food Policy Research Institute, USA, 38p

Heileselassie, H., Priess, J., Veldkamp, E., Demil, T., Lesschen, J.P. 2005. Assessment of soil nutrient depletion and its spatial variability on smallholders' mixed farming systems in Ethiopia using partial versus full nutrient balances. Agriculture Ecosystems and Environment. 108, 1-16.

Haileselassie, A., Priess, J.A., Veldkamp, E., Lesschen, J.P. 2006. Smallholders' soil fertility management in the Central Highlands of Ethiopia: implications for nutrient stocks balances and sustainability of agro-ecosystems. Nutrient Cycling in Agroecosystems. 75, 135-146. 
Inckel, M., de Smet, P., Tersmette, T., Veldkamp, T. 2005. The preparation and use of compost. Agrodok 8, Agromisa Foundation, Wageningen, the Netherlands.

Jones, J.B. 2003. Agronomic handbook: Management of crops, soils and their fertility. CRC Press, New York, USA, 482p

Kang, G.S., Beri, V., Sidhu,B. S., Rupela, O.P. 2005. A new index to assess soil quality and sustainability of wheat-based cropping systems. Biology and Fertility of Soils. 41, 389-398.

Mamo, T., Erkossa, T., Tulema, B. 2001. Soil fertility and plant nutrition research on tef in Ethiopia. In: H. Tefera, G. Belay, M. Sorrels (eds). Tef research and development in Ethiopia. Ethiopian Institute of Agricultural Research, Addis Ababa, Ethiopia, pp: 191-201.

Marschner, H. 1995. Mineral nutrition of higher plants. Institute of Plant Nutrition, University of Hohenheim, Academic Press, Harcour Brace, London, $892 \mathrm{p}$.

Matsi, T., Lithourgidis, A.S., Gagianas, A.A. 2003. Effects of injected liquid cattle manure on growth and yield of winter wheat and soil characteristics. Agronomy Journal. 95, 592-596.

Sanchez, P.A., Shepherd, K.D., Soule, M.J., Place, F.M., Buresh, R.J., Izac, M.N., Mokwunye, A.U., Kwesiga, F.R, Ndiritu, C.G., Woomer, P.L. 1997. Soil fertility replenishment in Africa: An investment in natural resource capital. In: R.J. Buresh, P.A. Sanchez, F. Calhoun (eds). Replenishing soil fertility in Africa. SSSA Special Publication No. 51. SSSA, Madison, WI, USA, pp: $1-46$.

Sanginga, N., Woomer, P.L. 2009. Integrated soil fertility management in Africa: Principles, practices and developmental process. Tropical Soil Biology and Fertility Institute of the International
Centre for Tropical Agriculture. Nairobi, Kenya, $263 p$.

Srivastava, P.K., Gupta, M., Upadhyay, R.K., Sharma, S., Singh, N., Tewari1, S.K., Singh, B. 2012. Effects of combined application of vermincompost and mineral fertilizer on the growth of Allium cepaL. and soil fertility. Journal of Plant Nutrition and Soil Science. 175, 101-107.

SAS. 2002. SAS/STAT user's guide, version 8.2, SAS Inst. Inc., Cary, NC, USA.

Sharma, P.K., Verma, T.S., Gupta, J.P. 1990. Ameliorating effects of phosphorus, lime and animal manure on wheat yield and root cation exchange capacity in degraded Alfisols of NorthWest Himalayas. Fertilizer Research. 23, 7-13.

Sinebo, W. 2002. Yield relationships of barley grown on a tropical highland environment. Crop Science. $42,428-437$.

Spielman, D., Kelemework, D., Alemu, D.2009. Policies to Promote Smallholder Intensification in Ethiopia: The Search for Appropriate Public and Private Roles, IFPRI, Addis Ababa, Ethiopia.

Våje, P.I. 2007. Soil fertility issues in Blue Nile Valley, Ethiopia. Advances in Integrated Soil Fertility Management in sub-Saharan Africa: Challenges and Opportunities. Springer Publishing, Dordrecht, the Netherlands, pp: 139-148.

Vanlauwe, B., Bationo, A., Chianu, J., Giller, K.E., Merckx, R., Mokwunye, U, Ohiokpehai, O., Pypers, P., Tabo, R., Shepherd, K.D., Smaling, M.A., Woomer, P.L., Sanginga, N. 2010. Integrated soil fertility management operational definition and consequences for implementation and dissemination. Outlook Agriculture. 39, 17 24.

Yirga, C., Tesfaye, A., Agegnehu,G., Asefa, G., Kenneni, G. 2002. Crop-livestock farming 
systems of the highlands of WelmeraWereda: the case of WelmeraGoro bench-mark site. In: G. Keneni, Y. Gojjam, C. Yirga (eds). Towards farmers' participatory research. EIAR, Ethiopia, pp: 147-174.
Zeleke, G., Agegnehu, G., Abera, D., Rashid, S. 2010. Fertilizer and soil fertility potential in Ethiopia: Constraints and opportunities for enhancing the system. IFPRI, Addis Ababa, Ethiopia, 63p. 